\title{
The Sociolinguistics Analysis of Address Terms in English and Enrekang-Durinese
}

\author{
Nurfitriana Zainal $^{1 *}$ and Kumara Tungga Dewa ${ }^{2}$ \\ ${ }^{1,2}$ Department of English Language Studies, Universitas Hasanuddin, Makassar, Indonesia \\ *nfistrianazainal@gmail.com
}

\begin{abstract}
This research is a sociolinguistics study that explores the relationship between language and society. The research aims to identify the address terms used in English and Enrekang-Durinese based on daily conversation. The research method used in this research is descriptive qualitative. The Enrekang-Durinese data is obtained by Recording and interviewing, which is done by Massenrempulu people in Duri, Alla' Sub-district, Enrekang District. The English data is obtained from English Movie and Series, which contain utterances of address terms. The research result shows the kind of address terms used in English and Enrekang-Durinese in daily conversations. They are 1) Pronoun (Second Person Pronoun), 2) Kinship Terms, and 3) Non-Kinship Terms. The difference between both languages appeared in Pronoun, Enrekang-Durinese has two types of Pronoun, Polite and Polite, while In English, there is only one-second person pronoun; you. Another difference is found in kinship and non-kinship terms. Enrekang-Durinese people usually use mockery to address family and relatives, while using mockery to address family and relatives is not found in English Data. Another result found in this research is that some aspects influence the use of the address terms in English and Enrekang-Durinese, they are 1) Sex and Age 2) Situation 3) Social Rank/ Social status.
\end{abstract}

Key words: Address term, Enrekang-Durinese, sociolinguistics.

\section{Introduction}

Address term is one sociolinguistics phenomenon that plays an essential role in communication. Address term provides valuable sociolinguistic information about the interlocutors, their relationship and their circumstances [1]. Brown and Gilman proposed the most influential study of address form and social relationship. Address terms is also a word or phrase from the speaker to the hearer in conversation. It is determined by the prevailing convention in society and several factors, such as gender, age, position, award, manner and kinship [2]. Every language knows the address terms used only to confine the user of a particular language in the community. Indonesia, for example, has various vernacular languages as it consists of many provinces with their vernacular languages [3]. One of the examples of vernacular language in Indonesia is Durinese. Durinese used by people in Enrekang Duri. Enrekang is one of the second level regions in the province of South Sulawesi, Indonesia. It is known as the city of agriculture.

Durinese people have unique ways to address one another. They tend to use mockery to address their relatives. It displays socio-cultural values as well as the community's social behavior and language. From those phenomena, 
the researchers are willing to examine more about address terms and the social relationship in Duri, Enrekang Massenrempulu District. But as the researchers know, there is not enough information about address terms in Enrekang-Durinese Language because it is rare to find other researchers' writing about address terms in EnrekangDurinese. Therefore, it will be interesting and informative to comprehend better how Enrekang-Durinese people use the address term. Based on that reason, the researchers want to elucidate more about the address term used by Enrekang-Durinese people to identify the differences and similarities with the use in English as the researchers' major in English language Study through sociolinguistics analysis.

\section{Theoretical Reviews}

The first work regarding addressing terms is a thesis written by Alharbi, entitled "A Socio-Pragmatic Study of Forms of Address and Terms of Reference in Classical Arabic as Represented in the Chapter of Joseph in the Holy Quran", [4]. The research explained the Classical Arabic terms of address and forms of reference used by the members of the society of the story of the Prophet Joseph as presented in the Holy Quran. The researchers found that addressing and the referring terms (nominal and pronominal) are extracted from the Quranic text to explore their linguistic features concerning number, case, and gender. Nevertheless, this research only mentioned aspects that influence the use of address terms in the Quranic.

The second work is written by Ijad Khalid, entitled, "Power relation and address terms in English and Buginess: A politeness study", [5]. The research indicated some kinds of address terms utilised in both languages. The difference in both languages appeared that the nobility terms are not accommodated in American English while endearment terms are not usual in Buginese. It is also found that the age difference, social situation, social status, social distance or degree of intimacy, equality, and marital status among the speakers determine the pattern of speech concerning the power relations.

The third thesis is written by Ahmad Rizal Abdullah, entitled, "Address Term in English and Konjones: A sociolinguistics Study", [6]. The research identified the address terms existing in English and Konjonese and analysed the aspects affecting using the address term in English and Konjonese in sociolinguistics perspectives. The result of this research showed the address term existing in English and Konjo Dialect in daily communication. The researchers found a distinct difference between the use of the address term in English and Konjonese. In English, the speakers sometimes used the first name of the address to show the closeness. At the same time, in the Konjo dialect, there is a particular title used to address people, particularly older ones.

The previous studies above present the complexity of the address terms used. The writer assumed that the research is relevant to the researchers' topic because the research focuses on the same field, which is the use of address terms. The previous studies showed various studies carried out on the address terms in many local languages in Indonesia. But, none of them is conducted with Enrekang-Durinese language as a local language that focuses on social relationships in daily conversation. It made the researchers interested in investigating the various address terms used in English and Enrekang-Durinese culture.

\section{Methodology}

The kind of research method used in this thesis is descriptive qualitative. The data of the research were English and Enrekang-Durinese daily conversation. For Enrekang-Durinese, the data has been taken by field research, observation and recordings of everyday utterances of Enrekang-Durinese [7]. Besides, the researchers did an interview to gain more information about the social relations, including the informants' personal life and other information. For English data, the researchers took the data of Address terms used in English Movies and series through screen-captured and translation. Thus, in collecting the data, the researchers employed some steps. Firstly, recording the conversation was done by people in the Enrekang-Durinese community. The recording was taken using a smartphone's recorder in various circumstances, such as family gatherings, markets, offices, the centre of health service, mosques and neighborhoods. Secondly, by applying purposive sampling, the researchers classified those data containing terms of address to be analysed. Thirdly, doing interviews with the chosen Informant. At last, the data collecting was conducted in three months [8].

In analysing the data, the researchers follow some steps. Firstly, the selected data were transcribed. By doing this, the researchers could quickly analyse the data. Secondly, transcribing the selected data and translating it into English. Next, make the classification of address terms in English and Enrekang-Durinese based on their differences and similarities. After that, the researchers describe the forms of address terms in English and Enrekang-Durinese and classify the aspects that influence the address terms used in both languages. Finally, data verification to draw the conclusion that answered all the questions proposed in this research. 


\section{Findings and Discussions}

Based on the research conducted in Alla' sub-district, Enrekang Regency, especially in the Durinese-speaker community, the researchers found various address terms used by Enrekang-Durinese-speakers. The researchers also examined the aspects that influence the use of address terms in English and Enrekang-Durinese in daily conversation.

Kind of address terms in English and Enrekang-Durinese

Pronouns (Second Person Pronoun)

Table 1. Second Person Pronoun

\begin{tabular}{|c|c|c|c|c|c|c|}
\hline \multirow[b]{2}{*}{ Pronoun (2nd person pronoun) } & \multicolumn{2}{|c|}{ Subject } & \multicolumn{2}{|c|}{ Object } & \multicolumn{2}{|c|}{ Possessive Adj } \\
\hline & English & Durinese & English & Durinese & English & Durinese \\
\hline Polite & You & Kita & You & -ki' kamu' & Your & $-\mathrm{ta}^{\prime}$ \\
\hline Impolite & You & Iko & You & $-k o$, komu & Your & $-\mathrm{mu}$ \\
\hline
\end{tabular}

Table 1 shows two parts of pronoun (2nd person) in English and Enrekang-Durinese. In Enrekang-Durinese, address terms of second-person pronoun consist of words and affixes such as, -ki, -kamu', -ta', considered polite terms while words and affixes such as, -ko, komu' mu', can be considered impolite terms in a particular situation

Table 2

\begin{tabular}{ll}
\hline Enrekang-Durinese & English \\
\hline D: bara miki, Indo? & D: are you full yet, Mother? \\
M: Edapa bene, benpa jolo to pangkandean jo sa'demu. & M: not yet, child. Give me the side dish beside you. \\
D: oiye', & D: okay \\
M: kumande toda moko kana. & M: eat it too \\
D: mangka issan piki kumande ku kumande toda. & D: I'll eat when you have eaten. \\
\hline
\end{tabular}

The conversation above was between a daughter (D) and her mother (M) in the kitchen when they had their lunch. It shows that there are two kinds of pronouns used by the speakers to address their interlocutor. The daughter always uses the terms ki, miki' to address her mother, while the mother uses the impolite form ko and mu to address her daughter. These terms are generally found in the daily conversation among people in Enrekang-Durinese due to society's hierarchical terms and power relations. While in English-speaking countries, only use one kind of second-person pronoun, you.

\section{Kinship Terms}

Kinship terms are the address terms for the blood relations. The address terms include address terms for parents (mother and father), address terms for grandparents (grandmother and grandfather), address terms for siblings (brother and sister), address terms for child and cousin nephew/niece, and address terms for marital relation (husband and wife).

Table 3. Address terms for parents (father and mother)

\begin{tabular}{ccccc}
\hline \multicolumn{2}{c}{ Address terms used father } & & \multicolumn{2}{c}{ Address terms used for mother } \\
\cline { 1 - 2 } \cline { 5 - 5 } English & Durinese & & English & Durinese \\
\hline Father & Ambe' & & Mother & Indo' \\
Dady/dad & Bapa' & & Mommy/mom & Mama' \\
Papa/pa & Papa & & Mama/ma & Ma' \\
Nickname & - & & Nickname & - \\
\hline
\end{tabular}

Address terms for parents (mother and father). The table above shows the example of the address terms for parents, father and mother, which exist in English and Enrekang-Durinese. In English, most people address their father with dad, daddy, father and his nickname. And the address terms for mother are; mom, mommy, mother, mama, and by name or nickname. In English, it is common to address their parents using their nicknames. They use some kind of address to show emphasis and intimacy between the children and the parents. Moreover, In Enrekang-Durinese, 
addressing parents using their nicknames is considered rude and impolite due to the local community's hierarchical culture and politeness system

Address terms for grandparents. There are various address terms to address grandparents (great grandfather, great grandmother, grandfather and grandmother) in English and Enrekang-Durinese. In English, it is common to address grandfather and grandmother by using grandpa, granddad, grandfather, grandmother, grandma, grammy, granny, even their First Name and nickname. The use of terms great grandfather and great grandmother are quite similar to the use of address terms for grandfather and grandmother because they rarely use affixes great- to address their great grandparents. Instead, they usually use the grandparents' name or nickname to address the grandparents to show their closeness within the family relationship. The use of words (grandpa and grandma) is frequently found as a sign of respect and politeness toward the elders in the family. Moreover, a grandchild addresses grandmother and grandfather based on the custom and the background in the family. The data can be seen below;

GD : An Apple? Whoa.

GM : It's a MacBook, darling

$\mathrm{U}$ : Don't forget your manners. Thank your grandma.

GM : Grandmother or Evelyn, will do just fine.

GD : thank you, Evelyn (movie: Gifted)

Unlike English, In Enrekang-Durinese, the grandchild does not address the grandparents by using their name because it is considered rude and inappropriate. People have to use a proper way to address their grandparents, such as; Nene', Ambe, Indo, Nene Indo, Nene' + name. In particular families, such as noble families, they use Pung Nenek, Nenek Pung, Iye' to address their grandparents.

Address terms for Uncle and Aunt. There are various address terms for uncle and aunt that are used in English and Enrekang-Durinese. In English, people address their uncle and aunt by using the terms uncle/aunty, uncle or aunt + name or just call them with name only or nickname. As can be seen on the data below;

$\mathrm{N}$ : Frank, I'm sorry. I'm really sorry.

$\mathrm{U}$ : Yeah, right. (movie: Gifted)

In Enrekang, the number of address terms for uncle and aunt in Enrekang-Durinese is more diverse than English. They are; om, tanta, ambe, indo, nickname, papa/ mama+child name. In Enrekang-Durinese, nephews can also greet their uncles using Names or nicknames only, depending on the age of the uncle or aunt. Usually, if they are still young and unmarried, addressing uncle or aunt by name is not considered impolite. But if the uncle or aunt is already married, the nephews must call their uncle or aunt using the term ambe ure/ Indo ure or om/tanta.

Address terms for siblings (brother and sister). The address terms for brother and sister used by Enrekang-Durinese people are nickname, mane, bene, papa/mama+child name for married brother and sister. In English, people usually address their brother and sister by using brother, sister, and nickname.

In Enrekang-Durinese, address terms for brother and sister do not differ much from English, especially when talking to the older or the younger sibling. Most of the Enrekang-Durinese people also address their brother or sister by using nicknames, which is appropriate in society. In Enrekang-Durinese, it is prevalent to address their brother or sister using mockery, for instance, by the addressee's physical appearance and habit. It can be seen from the data below.

$\mathrm{B}$ : We boneng, poeko tuu, nena pa na tiro ko mama ban.

$\mathrm{S}$ : Iyo la poemo te bolong. Pa umbrori mama?

$\mathrm{B}$ : pouting teeth, go back to the house. Mama' has been looking for you.

$\mathrm{S}$ : yeah, I'm on my way, Black. Where's mom?

The conversation above is made by the brother and sister. The brother did not use his sister's name to address her sister, nor did the sister to her brother. The brother uses boneng to address his sister because his sister has pouting teeth. And so the sister addresses her brother bolong, and ganjang means black and ugly because of his physical appearance. This kind of address term is very common in Enrekang-Durinese. That is their daily communication style. It is considered polite as long as a family member and close relatives do it. However, In English, it is considered rude and impolite to address brother and sister by physical appearance. Those terms are sensitive in English society because it is regarded as verbal violence or bullying.

Address terms for child and cousin nephew/niece. In English, parents usually address their children using the terms kid, boy, son, daughter, baby, sweetheart, by their first name, nickname, and even a pet name. It is to show the intimacy and affection between parents to the children.

F: oh..my lamb..

D: daddy..

Unlike English, Enrekang-Durinese people usually use the terms nak, mane, bene and mockery to address the child or children, nephew, niece and cousin. This kind of mockery is a unique way for the Enrekang-Durinese people 
to show their affections. The mockery can be a physical appearance perceived as lacking normal proportion, such as pettiness, deficiency, a flat nose, bad teeth, a short body, etc. Although it sounds harsh and highly impolite, the Enrekang-Durinese community does not take offense and assume that it is the common one in Enrekang-Durinese Society. This kind of term deals with one of the sociolinguistics theories on language and culture. This kind of address terms can be found only in Enrekang-Durinese. The researchers did not find similar things in English Because it is very rough and unacceptable to address someone by using mockery or physical appearance. The use of address terms by Enrekang-Durinese people can be seen from the data below:

Enrekang-Durinese

M: Oo penyyo, gorengngi dau jo bale le, sola Garagako teng

D: Iye' ma'

English

M: oo flat nose, don't forget to fry the fish and also make tea

D: yes, mom

In Enrekang-Durinese, it is common to address a child, younger cousin, niece and nephew by using their unique or strange habit to show closeness and the casual situation between them. In English, people generally address the nephew or niece by using nicknames and buddies. Because they tend to use casual relationships. In English, people usually do not consider age and social status to address cousins. In Enrekang-Durinese, people should consider their age and social status if they wish to address cousins due to etiquette terms.

Address terms for marital relation (husband and wife). In English, husband and wife address their spouse based on the situation, formal and informal. Generally, husband and wife will address their spouse by using Nickname. But in a formal situation, they use the terms Mr+Last Name or Sir to show respect and the spouse's face in front of their relatives. For informal situations, the husband or wife addresses their spouse by using endearment terms such as; honey, darling, sweetheart, baby love, etc. It is to show closed intimacy and fondness between them.

Unlike Enrekang-Durinese, English Society is quite expressive in expressing their feelings towards their partner. They do not hesitate to greet their partner with affectionate greetings even though they are in front of many people. In Enrekang, calling a partner with a loving greeting is generally only done when they are alone. This is because English and Enrekang have different cultural backgrounds, where English people are open about intimacy while EnrekangDurinese people tend to be closed. In English, address terms for husband and wife used by Enrekang-Durinese are not based on the situation. The most used address term for husband and wife in Enrekang-Durinese is mama and papa. After getting married, Enrekang-Durinese people have two different ways to address husband or wife. Before they become parents, mostly husband and wife address their spouse by using nicknames. After becoming parents, they address husband and wife using the terms Pa', papa, mama, ma/ mama'na + child's name, papa'na + child's name, ambe'na indo'na. The use varies depending on the family. One more different thing, in Enrekang-Durinese, using a nickname to address the spouse is appropriately used only by the husband. It is considered impolite for the wife to address her husband by nickname, especially in a family gathering or public place. It is because of the hierarchical power of gender that exists in Enrekang-Durinese.

\section{Non-Kinship Terms}

Non-kinship terms are non-family member relationships. The researchers formulated non-kinship terms into threepart. They are; 1) title and professional terms, 2) religious and nobility terms and 3) colleague and neighborhood. In English, there are various terms to address colleague and neighbors: $\mathrm{Mr}+\mathrm{LN}, \mathrm{Mr}$, Sir, Mrs, Miss, guy, and nickname. When someone interacts with someone not related in the family, it mostly appears in the occupational environment. In English, the term $\mathrm{Mr}$ refers to the young or older adult and married or unmarried man. Mrs is used to addressing married women. In the neighborhood situation, it is used to address the superior one, such as the leader, and it is used to show respect within the same community. It's not much different from the Durinese community. The address terms for colleagues and neighbors are also influenced by the situation and conditions of the community. In a formal situation, the community uses the terms Pak, Ibu, Mama'na/ Papa'na.

Moreover, in informal situations, people tend to use names or greetings. Enrekang-Durinese tends to use simple terms to address his neighbors. Although they often use address terms that tend to be worth the mockery, it has been considered normal by the community Enrekang-Durinese. This is in accordance with the customs of the people in Enrekang. They reveal the degree of their closeness by the use of address terms. The more intimate they are, the less polite they use. It's certainly different in English. They do not use mock as a tool to address colleagues and neighbors because it is considered rude and not accepted by the community.

\section{Title and Professional Terms}

It has been mentioned before, the variety of address terms for title and professional terms used by English and Enrekang-Durinese. The address terms used in English mostly use Mr/Mrs+ Last Name, Sir and First name and title of the job to address people professionally in the workplace. Similarly, with Enrekang-Durinese, the title and professional address terms using Pak/ Bapak, Bu/ Ibu + job title can be seen from the table above. Generally, the 
address terms for title and professional used in Enrekang-Durinese have derived from Bahasa Indonesia since there is no equal translation in Durinese Language. It is also because of the title job or profession dealing with educational background or for those who go to the education institution. Both in English and Enrekang-Durinese use similar terms due to show respect to the addressee.

\section{Religious Terms}

There are commonplace existing address terms for religious terms used by American English society are Christian such as Father, Pastor, Priest, and Nun because the majority of American society is Christian. Those address terms are generally used in religious places and religious conversations. Enrekang-Durinese community is dominated by Muslims. Hence, the most frequent and common address terms for religious terms used by the people of EnrekangDurinese are Pak Ustas and Haji / Aji. The address terms are generally an absorption language from Arabic as the country that spreads the religion of Islam in the world. Enrekang-Durinese people not only use the religious address terms in places of worship such as mosques and religious studies, but they also use religious address terms wherever and whenever they meet the pious person to show respect. Enrekang-Durinese is a compulsion in culture to address someone using Haji or Aji after following the hajj ritual in Saudi Arabia. It is used to show respect to the religious title. This kind of address terms should be adhered to since it also shows the rank of someone in the community. That is very important for the participant to maintain FTA in politeness theory.

\section{Aspects Which Influence the Use of Address Terms in English And Enrekang-Durinese}

\section{Social Situation}

In a formal situation, as Brown and Levinson explained, related to the negative politeness that consists of assurances that recognises and the speaker respects the addressee's wants and will not interfere with the addressee's freedom negative politeness of action [9]. Therefore, it is characterized by self-effacement, formality and restraint, with attention to very restricted aspects of the hearer's self-image. In a formal situation or sometimes done in the occupational place, like School, office, University, Ceremony, social status of the speaker, etc. Formal address terms used in English have various terms such as Sir, Mr, Mrs, Miss, Ladies, Ma'am, ladies, and Gentlemen. Similarly, in Enrekang-Durinese, people use Pak' and Ibu/Bu' to address the formal situation. The terms are sometimes added with the first name and the name of the profession, such as Pa' Cama', Ibu Cama', Ibu' desa, Pa' dotter, Ibu dotter, Bu' bidan, $\mathrm{Bu}$ ' guru, $\mathrm{Pa}$ ' ustadz and $\mathrm{Pa}$ ' Imam, etc. In a formal situation, the second person pronoun that indicates politeness is more frequently used to maintain harmony in the social community.

In an informal situation, the Enrekang-Durinese community generally uses casual language to show an attitude of kinship. In addition to using nicknames, they usually use a mocking greeting in non-formal situations. For example, they address a friend using words that look the same as his physical appearance, such as "Hai bolong!" where bolong means (black). Things like this are not considered a bad thing for those who are greeted. Even this way of greeting is indicated as a way to show a degree of closeness in relationships. The more casual the language used, the closer the relationship is.

\section{Age Difference}

Wardaugh introduced the term of age-grading that young children speak differently from older children, and in turn, children speak differently from mature adults [10]. In addition, Fasold stated that in the different social contexts, an individual would talk in different ways where it can be influenced by terms of age, gender, social class and ethnic group [11]. Hence it can be identified that the use of the address is influenced by age. In English, particularly in a family environment, the children speak to the adult by using the particular address and receive the nickname from the adult; however, in some families in America, sometimes the children only address their parents with the name. In Enrekang-Durinese, there are also particular terms used to address the adult. Still, it is prohibited for the children to address the adult-only by the adult's name, especially a married man because the speakers will be considered impolite and rude.

\section{Social Distance and Social Status}

In social life, there must be a social distance that separates one individual from another. The way people talk and behave with each other shows their evaluation of themselves and the other interlocutors in the interaction. Brown and Levinson stated Social distance is the relationship between speaker and hearer in communication. If two people are very close, they have a low degree of social distance, and they usually do not use polite words to speak with each other and vice versa [9]. Power refers to the power relationship in communication like a position in society, age and social status. There are three kinds of power relationships. The first is equal power between friends and colleagues. The second is someone who has a more powerful relationship, like a boss, teacher or lecturer. The third is a less strong relationship like a brother, sister and student.

This research aims to analyse and compare the address terms existing in English and Enrekang-Durinese in daily communication. In this research, the researchers find several phenomena related to the use of the address terms, 
particularly those existing in a particular environment, such as family, non-family and occupational. The family environment involves the address terms of father, mother, grandfather, grandmother, uncle, aunty, son, daughter, cousin, and nephew. The phenomena existing in the address terms in American-English and Enrekang-Durinese society are similar. When the younger members address the adult, they should use a particular term to be more polite and respectful

\section{Conclusion}

The main point of this paper is to reveal the kind of address terms used in English and Enrekang-Durinese. They are: a) Second Person Pronouns. In Enrekang-Durinese, there are two types of second-person pronouns. Polite and impolite. They use; ki, kita, kamu' and iko', ko' ko' komu' as impolite second-person pronouns for polite pronouns. In English, there is only one-second person pronoun; you. b) Address terms for kinship terms. In Enrekang-Durinese, there use Papa, Mama, Indo, Ambe, Om, Tanta, Pak, Ibu, Bapak, Nenek, nak, mockery etc., while in English, there are: Great Grandfather, Great Grandmother, mother, Father, Dad, Mom, Grandmother, Grandfather, Uncle, Aunty, Son, Daughter, etc. c) Address terms for non-kinship terms. There are three types of address terms for non-kinship: Colleagues and neighborhood terms, Title and professional terms, and Religious and Nobility terms. For instance, In English: Mr, sir, First Name, Doctor, Nurse, Pastor, priest, father, Pope, nun, etc. In Enrekang-Durinese; Ambe, Indo, Tanta, Om, Mane, ne, Pak, Ibu Camat, Ibu/Pak Polisi, Dokter, Fistname and mockery.

\section{References}

[1] F. Braun, Terms of Address: Problems of Patterns and Usage in Various Languages and Cultures, New York: Mouton de Gruyter, 1988

[2] J. Blommaert, Discourse: Key Topics in Sociolinguistics, New York: Cambridge University Press, 2005.

[3] Brown, Roger, and A. Gilman, The Pronouns of Power and Solidarity in Style in Language, New York: Wiley, 1960.

[4] T. A. A. Alharbi, "A Socio-pragmatic Study of Forms of Address and Terms of Reference in Classical Arabic as Represented in the Chapter of Joseph in the Holy Quran," PhD dissertation, University of Leeds.Braun, Friederike. 1988.

[5] I. Khalid, "Power relation and address terms in English and Buginese: Apoliteness study," Graduate thesis, English Department, Universitas Hasanuddin, 2016.

[6] A. R. Abdullah. "Address Term in English and Konjones: A sociolinguistics Study," Graduate thesis, English Department, Universitas Hasanuddin, 2019.

[7] J. P. Spradley, Participant Observation, New Jersey: Holt Rinehart and Winston, 1980

[8] Sugiyono. Metode Penelitian Kuantitatif Kualitatif dan R\&D, Bandung: Alfabeta, 2014.

[9] P. Brown, and S. Levinson, Politeness: Some universals in language usage, UK: Cambridge University Press, 1987

[10] R. Wardhaugh, An Introduction to Sociolinguistics, New Jersey: Blackwell Publishing. 2001.

[11] R. Fasold, Sociolinguistics of Language, Cambridge: Basil Blackwellinc, 1990. 